\title{
Penerapan Strategi Learning Contract dalam Meningkatkan Hasil Belajar Siswa SMP
}

\author{
Muizudin \\ SMP Negeri I Sumber Kabupaten Cirebon \\ e-mail: muizudinjawahir@gmail.com
}

\begin{abstract}
Science is a branch of science that studies life. In science learning, it is emphasized that there are direct experiences experienced by students. In this context, a student must use scientific methods, namely exploring knowledge through investigation or research, communicating his knowledge to others, using thinking skills, using scientific attitudes and values. The purpose of this research is to improve student learning outcomes by implementing the Learning Contract strategy on static electricity in class IX A students of SMP Negeri I Sumber Cirebon Regency. Based on the research results obtained, the authors draw the following conclusions: 1). That the Learning Contract strategy can be implemented as a learning strategy on the subject matter of static electricity in class IX A SMP Negeri I Sumber, Cirebon Regency 2). The number of cycles needed to increase creativity in thinking and learning activities $L P A$ class IX A students of SMP Negeri I Sumber Cirebon Regency is 3 cycles. Some suggestions that the author can submit include: 1). The school should conduct classroom action research (CAR) more often as an effort to improve learning outcomes 2). For the world of education, it can be used as a contribution to the treasury of educational development 3). Teachers should be able to apply this strategy as an alternative learning strategy to improve learning outcomes
\end{abstract}

Keywords: learning contract, learning outcomes, science

\begin{abstract}
ABSTRAK
IPA merupakan cabang ilmu sains yang mempelajari tentang kehidupan. Dalam pembelajaran sains ditekankan adanya pengalaman langsung yang dialami siswa. Dalam konteks ini seorang siswa harus menggunakan metode-metode ilmiah yaitu menggali pengetahuan melalui penyelidikan atau penelitian, mengkomunikasikan pengetahuannya kepada orang lain, menggunakan keterampilan berpikir, menggunakan sikap dan nilai ilmiah. Tujuan dilakukannya penelitian ini adalah meningkatkan hasil belajar siswa dengan menerapkan strategi Learning Contract pada materi Listrik statis pada siswa kelas IX A SMP Negeri I Sumber Kabupaten Cirebon. Berdasarkan hasil penelitian yang didapatkan, penulis menarik kesimpulan sebagai berikut: 1). Bahwa strategi Learning Contract dapat dilaksanakan sebagai strategi pembelajaran pada materi pokok Listrik statis di kelas IX A SMP Negeri I Sumber Kabupaten Cirebon 2). Banyaknya siklus yang dibutuhkan untuk dapat meningkatkan kreativitas berpikir dan aktivitas belajar [PA siswa kelas IX A SMP Negeri I Sumber Kabupaten Cirebon adalah sebanyak 3 siklus. Beberapa saran yang dapat penulis ajukan antara lain: 1). Bagi pihak sekolah hendaknya lebih sering melakukan penelitian tindakan kelas (PTK) sebagai salah satu usaha untuk memperbaiki mutupembelajaran 2). Bagi dunia pendidikan, dapat dijadikan sebagai sumbangan bagi khazanah pengembanganpendidikan 3). Bagi Guru hendaknya dapat menerapkan strategi ini sebagai salah satu strategi pembelajaran alternatif untuk meningkatkan mutu pembelajaran.
\end{abstract}

Kata Kunci: learning contract, hasil belajar, IPA

Submitted Apr 17, 2021 | Revised May 04, 2021 | Accepted May 06, 2021

\section{Pendahuluan}

IPA merupakan cabang ilmu sains yang mempelajari tentang kehidupan. Dalam pembelajaran sains ditekankan adanya pengalaman langsung yang dialami siswa (Kumara, 2004; Juhji, 2017; Suhendi, 2017; Eliyana, 2020). Dalam konteks ini seorang siswa harus menggunakan metode-metode ilmiah yaitu menggali pengetahuan melalui penyelidikan atau penelitian, mengkomunikasikan pengetahuannya kepada orang lain, menggunakan keterampilan berpikir, menggunakan sikap dan nilai ilmiah ((A'yun, et al., 2015; Azizah \& Winarti, 2016; Harefa, 2016; Fitriana, 2017). Kemampuan-kemampuan siswa sebagaimana telah disebutkan di atas jika digandeng dengan tujuan pendidikan bertujuan menyiapkan 
siswa menjadi mandiri dan belajar seumur hidup, menuntut guru untuk memodifikasi cara penyampaian konten dan cara belajar siswa.

IPA bukan hanya sekedar menghafalkan konsep dan prinsip IPA melainkan, dengan pembelajaran IPA diharapkan siswa dapat memiliki sikap dan kemampuan yang berguna bagi dirinya dalam memahami perubahan yang terjadi dilingkungannya dan berprestasi dalam pelajaran IPA ((Wati, et al., 2015; Sulthon, 2016; Tias, 2017). IPA berhubungan dengan cara mencari tahu tentang alam secara sistematis, sehingga IPA bukan hanya penguasaan kumpulan pengrtahuan yang berupa fakta-fakta, konsep-konsep, atau prinsip-prinsip saja tetapi juga merupakan suatu proses penemuan (Irjan, 2008; Halidjah \& Margiati, 2014; Saputro, 2017).

Berdasarkan hasil observasi, dalam kegiatan Pembelajaran Fisika di kelas IX A SMP Negeri I Sumber Kabupaten Cirebon, kelas IX A terlihat masih banyak siswa yang duduk diam, beberapa siswa kadang bercanda atau ngobrol dengan teman, menyandarkan kepala di atas meja, enggan bertanya, jika pun ada hanya satu dua orang, menjawab pertanyaan dengan ragu, kurang berani mengemukakan ide atau gagasan, menulis pelajaran jika disuruh atau malah lebih banyak menulis pelajaran dibanding mendengarkan penjelasan guru, melakukan kegiatan pembelajaran jika perintah guru, dalam kegiatan kelompok sebagian siswa masih pasif, dan belum mampu mengkomunikasikan hasil pekerjaan kepada teman di hadapan kelas. Kenyataan ini menunjukkan bahwa siswa masih cenderung pasif dalam melaksanakan kegiatan belajar. Sebenarnya, guru telah menggunakan beberapa metode mengajar dalam melaksanakan kegiatan belajar seperti metode tanya jawab, ceramah, diskusi, praktikum baik di laboratorium maupun di luar laboratorium serta pemberian tugas baik di kelas maupun di rumah. Namun penggunaan metode-metode tersebut nampaknya belum mampu memacu siswa untuk aktif karena siswa masih senang bergantung kepada guru sebagai sumberutama.

Strategi Learning Contract adalah salah satu strategi belajar yang dapat diterapkan guru untuk melibatkan siswa secara langsung dalam proses pembelajaran (Apriyani, 2016; Suhara \& San Fauziya, 2017; Fitria, 2019). Strategi Learning Contract merupakan salah satu bentuk strategi belajar aktif dan mandiri, di mana siswa membuat sebuah kontrak belajar yang terdiri dari tujuan belajar, kompetensi yang ingin dicapai, jenis kegiatan, bukti dan waktu penyelesaian yang kemudian dijadikan acuan dalam melaksanakan kegiatan belajarnya. Dengan alasan inilah kemudian peneliti memilih strategi Learning Contract sebagai strategi yang akan digunakan dalam rangka meningkatkan mutu pembelajaran di kelas IX A SMP Negeri I Sumber Kabupaten Cirebon

\section{Metode Penelitian}

Metode penelitian yang digunakan adalah Penelitian Tindakan Kelas yaitu suatu kajian sistematik dari upaya perbaikan pelaksanaan praktek pendidikan oleh sekelompok guru dengan melakukan tindakan-tindakan dalam pembelajaran, berdasarkan refleksi mereka mengenai hasil dari tindakantindakan tersebut (Jasmin, et al., 2015; Nurdin, 2017; See, et al., 2021). Untuk mewujudkan tujuantujuan Penelitian Tindakan Kelas tersebut dilaksanakan dalam proses penyajian berdaur yang terdiri dari 4 tahap yaitu: merencanakan, melakukan tindakan, mengamati, dan merefleksi. Setelah melakukan tindakan refleksi yang mencakup analisis, sistesis dan penilaian terhadap hasil pengamatan proses dan hasil tindakan yang dilakukan, biasanya muncul permasalahan atau pemikiran yang perlu mendapat perhatian, sehingga pada gilirannya perlu dilakukan perencanaan ulang, tindakan ulang, pengamatan ulang serta diikuti dengan refleksi ulang. Tahap-tahap kegiatan ini terus berulang sampai suatu permasalahan dianggap selesai.

Penelitian ini mengambil bentuk penelitian tindakan kelas, di mana peneliti berkolaborasi dengan guru mata pelajaran IPA yang lain di SMP Negeri I Sumber Kabupaten Cirebon membentuk satu tim untuk melakukan penelitian dengan tujuan untuk memperbaiki kekurangan-kekurangan dalam praktek pembelajaran. Hubungan anggota dalam tim kolaborasi bersifat kemitraan, sehingga kedudukan peneliti 
dengan guru mata pelajaran adalah sama. Kolaborasi tim berfungsi untuk memikirkan persoalanpersoalan yang akan diteliti dalam penelitian tindakan.

Instrumen yang diperlukan untuk keperluan pengambilan data dalam penelitian adalah dengan menggunakan lembar observasi dan soal divergen. Observasi berguna untuk mengidentifikasi aktivitas siswa di kelas selama proses pembelajaran. Selain lembar observasi, digunakan juga soal divergen sebagai instumen untuk mengidentifikasi tingkat berpikir siswa. Data aktivitas belajar siswa dalam pembelajaran dianalisis secara deskriptif dengan persentase. Data tingkat kreativitas berpikir siswa dalam menjawab soal divergen dianalisis dengan deskripsi menggunakan persentase. Data berupa skor yang diperoleh siswa berdasarkan skor tiap bobot jawaban kemudian dijumlah.

\section{Hasil dan Pembahasan}

Belajar yang timbul dari keinginan sendiri acapkali akan lebih mendalam dan permanen ketimbang belajar yang diarahkan oleh guru.Dengan demikian dibutuhkan suatu strategi untuk dapat melaksanakan kondisi belajar yang demikian. Strategi Learning Contract dilakukan sebagai tindakan kelas dengan tujuan agar aktivitas belajar yang dilakukan siswa hasilnya akan lebih mendalam dan lebih aplikatif sehingga mampu memacu kreativitas berpikir siswa.

\section{Pelaksanaan Strategi Learning Contract}

Berdasarkan hasil observasi yang dilakukan baik oleh observer, kolaborator maupun peneliti sendiri, strategi Learning Contract dapat dilaksanakan sebagai strategi pembelajaran pada materi pokok lstrik statis di kelas IX A SMP Negeri I Sumber Kabupaten Cirebon. Hal ini bisa terlihat pada pembelajran siswa di mana masing-masing siswa melakukan kegiatan belajar sesuai dengan topik yang mereka pilih untuk mereka pelajari. Dengan siswa memilih sendiri kegiatan yang akan dipelajarinya, siswa akan mampu melakukan kegiatannya sendiri tanpa harus selalu bergantung kepada guru. Selain itu, siswa juga diajarkan untuk bertanggungjawab terhadap keterlaksanaan kegiatan belajar meraka dan terhadap hasil belajar yang sudah mereka buat dalam kontrak belajar.

Learning Contract (kontrak belajar) dibuat oleh siswa pada awal sebelum materi dipelajari dengan tujuan agar siswa mampu mengonsep dan memanajemen kegiatan yang harus mereka lakukan. Kemudian siswa dilepaskan untuk melakukan kegiatan belajar bersama masing-masing kelompoknya. Pada akhir kegiatan pembelajaran siswa menunjukkan bukti pelaksanaan kegiatan yang sudah mereka lakukan sesuai dengan bukti yang mereka buat dalam kontrak. Hal ini dimaksudkan untuk mengontrol sejauh mana siswa melaksanakan tanggung jawabnya. Beberapa bukti yang dibuat siswa adalah berupa laporan hasil pengamatan, resume dari kajian literatur, laporan hasil analisis.

Kontrak belajar yang dibuat siswa adalah kontrak belajar kelompok, di mana beberapa siswa yang tergabung dalam satu kelompok membuat rancangan kegiatan yang akan dilakukan untuk dapat menguasai suatu materi. Kontrak belajar yang dibuat kelompok ini disesuaikan dengan topik pembelajaran yang dipilih oleh masing-masing kelompok. Jadi, setiap kelompok mendapatkan topik dan jenis kegiatan yang berbeda. Agar setiap siswa dalam kelompok melakukan aktivitas belajar, maka dibuat pembagian tugas. Karena setiap kelompok mendapatkan tugas yang berbeda, sehingga aktivitas yang dilakukan pun ada yang berbeda-beda sesuai dengan jenis kegiatannya. Seperti kelompok 1 dengan topik struktur dan fungsi otot, tulang dan sendi pada manusia diantara kegiatan yang dilakukannya adalah melakukan pengamatan Listrik statis. Jenis kegiatan ini tidak dilakukan oleh kelompok 2, 3, dan 4. begitupun dengan kelompok 2 yang salah satu kegiatannya adalah meperagakan proses terjadinya gerak. Jenis kegiatan ini juga tidak dilakukan oleh kelompok 1, 3, dan 4. sedangkan untuk jeniskegiatan melakukan kajian literatur, hampir semua kelompok melakukannya. Menurut Sardiman A.M., belajar sangat diperlukan adanya aktivitas, tanpa aktivitas belajar maka proses belajar tidak mungkin dapat terlaksana.

Berdasarkan pengamatan, dengan menggunakan strategi Learning Contract ini aktivitas belajar siswa mengalami peningkatan dan lebih bervariasi. Selain itu, karena strategi ini lebih membebaskan siswa 
untuk mencari sebanyak-banyaknya bahan untuk belajar, sehingga dapat memacu kreativitas berpikir mereka, dan ini dibuktikan dari hasil jawaban siswa ketika menjawab tes soal divergen. Rata-rata jawaban siswa bervariasi dan sangat orisinil sesuai dengan pengetahuan siswa. Jawaban siswa lebih aplikatif dan tidak hanya terpaku pada informasi dari buku referensi saja.

Strategi learning contract sebagai tindakan untuk memeperbaiki kualitas pembelajaran siswa mungkin akan lebih baik jika diterapkan untuk kegiatan belajar inidividual, hanya saja pelaksanaannya akan sangat sulit karena membutuhkan setting dan planing yang begitu banyak, apalagi mengingat ini digunakan dalam sebuah penelitian. Sehingga untuk mempermudah dalam mengambil data maka digunakanlah kontrak belajar kelompok.

Meskipun demikian, berdasarkan hasil pengamatan strategi ini sangat efektif untuk digunakan dalam rangka meningkatkan aktivitas belajar dan kreativitas berpikir siswa karena dalam strategi ini siswa lebih banyak diberikan waktu untuk belajar sendiri (pembelajaran yang demokratis) sehingga pengalaman yang didapatkan siswa lebih banyak dari pada hanya mengandalkan informasi dari guru. Namun demikian, guru sebagai fasilitator tetap perlu mendampingi siswa sehingga keterlaksanaan pembelajaran dengan strategi ini membuahkan hasil yang baik. Untuk lebih jelasnya aktivitas dan kreativitas berpikir apa saja yang terjadi dalam setiap siklusnya akan dibahas pada pembahasan selanjutnya.

2. Banyaknya Siklus untuk Mencapai Peningkatan Kreativitas Berpikir dan Aktivitas Belajar Siswa

Berdasarkan hipotesis yang diajukan dalam penelitian ini, setidaknya dibutuhkan 3 siklus untuk dapat meningkatkan kreativitas berpikir dan aktivitas belajar siswa kelas IX A SMP Negeri I Sumber Kabupaten Cirebon. Hipotesis ini diajukan berdasarkan pertimbangan atas hasil observasi di mana masih banyak siswa yang terlihat pasif dalam melakukan kegiatan belajar. Selain itu, kreativitas berpikir siswa juga masih terbatas pada informasi dari buku-buku yang tersedia di sekolah.

Pada siklus I, kegiatan belajar yang dilakukan belum maksimal dikarenakan jam belajar mengalami pemotongan dari 90 menit pada biasanya menjadi hanya 60 menit saja dan jumlah siswa yang hadir sebanyak 28 orang. Pada siklus I siswa melakukan berbagai kegiatan di antaranya melakukan kajian literatur di perpustakaan, melakukan percobaan, melakukan pemodelan, dan melakukan pengamatan. Namun karena waktu yang tersedia terbatas sehingga semua kegiatan-kegiatan tersebut tidak bisa diselesaikan dan harus dilanjutkan pada siklus selanjutnya. Meskipun kegiatan-kegiatan ini sudah mulai berjalan, tetapi aktivitas siswa masih rendah. Hal ini terlihat dari rata-rata nilai aktivitas belajar siswa sebesar $19.33 \%$ dan kreativitas berpikir siswa sebesar 10.94\%. Hal ini mungkin diakibatkan karena kurangnya koordinasi dan pembagian tugas dalam kelompok sehingga pada satu kelompok ada yang anggotanya aktif semua tapi ada juga kelompok yang tidak semua anggotanya ikut berpartisipasi dalam kegiatan kelompoknya. Aktivitas-aktivitas yang dilakukan siswa pada siklus ini antara lain membaca buku referensi $99.99 \%$, mengamati gambar/skema $81.09 \%$, bertanya $61.1 \%$, mengamati $72.21 \%$, menjawab pertanyaan $33.32 \%$, persentasi $27.77 \%$, menanggapi pertanyaan $44.43 \%$, melakukan diskusi $50 \%$, mendengarkan persentasi/diskusi $27.77 \%$, menerima pendapat $83.32 \%$, membuat resume $49.99 \%$, membuat laporan $72.21 \%$, menulis hasil diskusi/presentasi $66.66 \%$, mengerjakan tugas $83.31 \%$, menjelaskan $61.1 \%$, melakukan pengamatan / percobaan $33.32 \%$, melakukanpemodelan $16.66 \%$, membuat model $22.22 \%$, menganalisis $27.77 \%$, melakukan studi literatur $94.43 \%$, membuat skema/gambar $27.77 \%$. Sedangkan persentase kreativitas berpikir siswa berdasarkan observasi kriteria jawaban terhadap soal divergen pada siklus I yaitu siswa menghasilkan banyak gagasan/jawaban yang relevan sebesar 100\%, arus pemikiran lancar sebesar 88.88\%, menghasilkan gagasan-gagasan yang seragam sebesar $83.33 \%$, mengembangkan, menambah, memperkaya suatu gagasan sebesar $100 \%$, dan memberikan jawaban yang tidak lazim, yang lain dari yang lain, yang jarang diberikan kebanyakan orang sebesar $77.77 \%$.

Pada siklus II kegiatan belajar yang dilakukan adalah lanjutan dari siklus sebelumnya. Berdasarkan hasil observasi, pada siklus ini terjadi peningkatan rata-rata nilai aktivitas belajar siswa sebesar $22.52 \%$ 
dan kreativitas berpikir siswa meningkat menjadi sebesar 12\%. Pada siklus II ini jam belajar berjalan normal yakni selama 90 menit dan jumlah siswa yang hadir sebanyak 32 orang. Aktivitas-aktivitas yang masih dilakukan siswa antara lain membaca buku referensi 95.23\%, mengamati gambar/skema $66.65 \%$, bertanya $76.18 \%$, mengamati/observasi $61.9 \%$, menjawab pertanyaan $33.33 \%$, persentasi $33.32 \%$, menanggapi pertanyaan $52.37 \%$, melakukan diskusi $47.6 \%$, mendengarkan presentasi/diskusi $52.36 \%$, menerima pendapat $85.7 \%$, membuat resume $47.6 \%$, membuat laporan $99.99 \%$, menulis hasil diskusi/presentasi 72.22\%, mengerjakan tugas 76.17\%, menjelaskan 57.13\%,melakukan pengamatan/percobaan 33.33\%, melakukan pemodelan 33.32\%, membuat model $23.80 \%$, menganalisis $33.33 \%$, melakukan studi literatur $99.99 \%$, membuat skema/gambar 23.80\%. Sedangkan persentase kreativitas berpikir siswa pada siklus II mengalami peningkatan dan penurunan. Aspek yang mengalami peningkatan yaitu siswa mampu mengembangkan, menambah, memperkaya suatu gagasan sebesar $80.95 \%$ dan memberikan jawaban yang tidak lazim, yang lain dari yang lain, yang jarang diberikan kebanyakan orang sebesar sebesar 100\%. Untuk aspek kreativitas yang lain mengalami penurunan yaitu arus pemikiran lancar $85.71 \%$, menghasilkan gagasan-gagasan yang seragam sebesar $76.19 \%$, dan menghasilkan banyak gagasan/jawaban yang relevan $71.42 \%$. Berdasarkan hasil kegiatan yang dilakukan siswa, terjadi fluktuasi aktivitas belajar siswa yakni terjadi peningkatan dan penurunan persentase pada beberapa aktivitas. Selain itu, rangkaian kegiatan yang harus dilakukan siswa belum selesai sehingga diputuskan untuk melanjutkan pembelajaran pada siklus ketiga.

Pada Siklus II Pertemuan Ke-2, siswa melakukan kegiatan terakhir untuk menyelesaikan materi Listrik statis, yakni siswa melaporkan hasil kegiatan yang sudah dilakukan dalam bentuk presentasi di depan kelas. Selain untuk melaporkan hasil kegiatan, presentasi juga dimaksudkan sebagai media untuk bertukar informasi antar kelompok. Karena masing-masing kelompok mendapatkan topik yang berbeda, sehingga agar semua kelompok mendapatkan bahan materi yang utuh serta dapat memahami materi tersebut dibutuhkan presentasi untuk saling tukarinformasi.

Pada Siklus II Pertemuan Ke-2, rata-rata nilai aktivitas belajar siswa mengalami peningkatan sebesar $27.68 \%$ dan kreativitas berpikir siswa meningkat menjadi $14.68 \%$. Adapun aktivitas-aktivitas yang masih dilakukan siswa pada siklus ini adalahmembaca buku referensi $99.98 \%$, mengamati gambar/skema99.99\%, bertanya $99.99 \%$, mengamati $89.46 \%$, menjawab pertanyaan $47.36 \%$, presentasi $52.61 \%$, menanggapi pertanyaan $73.67 \%$, melakukan diskusi $57.87 \%$, mendengarkan presentasi/diskusi $99.99 \%$, menerima pendapat $84.19 \%$, membuat resume $94.72 \%$, membuat laporan $99.98 \%$, menulis hasildiskusi/presentasi $73.67 \%$, mengerjakan tugas $99.99 \%$, menjelaskan $68.4 \%$, melakukan pemodelan 47.35\%, membuat model 31.57\%, menganalisis $89.46 \%$, melakukan studi literatur $99.99 \%$, membuat skema/gambar 26.31\%. Sedangkan persentase kreativitas berpikir siswa berdasarkan observasi kriteria jawaban terhadap soal divergen pada Siklus II Pertemuan Ke-2 yaitu siswa menghasilkan banyak gagasan/jawaban yang relevan sebesar 100\%, arus pemikiran lancar sebesar $89.47 \%$, menghasilkan gagasan-gagasan yang seragam sebesar 100\%, mengembangkan, menambah, memperkaya suatu gagasan sebesar $94.73 \%$, dan memberikan jawaban yang tidak lazim, yang lain dari yang lain, yang jarang diberikan kebanyakan orang sebesar $94.73 \%$.

3. Peningkatan yang Terjadi pada TiapSiklus

Setelah dilakukan observasi dan analisis, pada setiap siklus terjadi peningkatan. Pada aktivitas belajar, peningkatan itu sebesar 3.19\% pada siklus II (dari 19.33\% pada siklus I menjadi $22.52 \%$ pada siklus II), dan peningkatan aktivitas pada Siklus II Pertemuan Ke-2 sebesar 5.16\% (dari 22.52\% pada siklus II menjadi 27.68\% pada Siklus II Pertemuan Ke-2). Sedangkan pada kreativitas berpikir siswa peningkatan yang terjadi sebesar $1.6 \%$ (dari $10.94 \%$ pada siklus I menjadi $12 \%$ pada siklus II), dan $2.68 \%$ (dari $12 \%$ pada siklus II menjadi $14.68 \%$ pada siklusIII).

Sebagaimana pada aktivitas belajar siswa, pada kreativitas berpikir siswa juga mengalami peningkatan dan penurunan. Pada siklus II, peningkatan persentase kreativitas berpikir terlihat pada kemampuan siswa dalam mengembangkan, menambah, memperkaya suatu gagasan yakni dari $77.77 \%$ 
pada siklus I menjadi $80.95 \%$ dan memberikan jawaban yang tidak lazim, yang lain dari yang lain, yang jarang diberikan kebanyakan orang sebesar tetap sebesar 100\%. Adapun penurunan terjadi pada ketiga aspek kreativitas berpikir yang lain yaitu arus pemikiran lancar dari $85.71 \%$,menghasilkan gagasangagasan yang seragam sebesar $76.19 \%$, dan menghasilkan banyak gagasan/jawaban yang relevan $71.42 \%$

Pada setiap siklus, terjadi fluktuasi aktivitas siswa. Adapun jenis-jenis aktivitas yang mengalami peningkatan antara lain tampak pada bebrapa tabel berikut 1 .

Tabel 1. Perbandingan Peningkatan Aktivitas Belajar pada Siklus I dan II

\begin{tabular}{clcc}
\hline No. & \multicolumn{1}{c}{ Aktivitas Siswa } & \multicolumn{2}{c}{ Persentase $(\%)$} \\
& & Siklus I & Siklus II \\
\hline 1 & Bertanya & 61.1 & 76.18 \\
2 & Menjawab pertanyaan & 33.32 & 33.33 \\
3 & Presentasi & 27.77 & 33.32 \\
4 & Menanggapi pertanyaan & 44.43 & 52.37 \\
5 & Mendengarkan presentasi/diskusi & 27.77 & 52.36 \\
6 & Menerima pendapat & 83.32 & 85.7 \\
7 & Membuat laporan & 72.21 & 99.99 \\
8 & Menulis hasil diskusi /presentasi & 66.66 & 72.22 \\
9 & Melakukan pengamatan/percobaan & 33.32 & 33.33 \\
10 & Melakukan pemodelan & 16.66 & 33.32 \\
11 & Membuat model & 22.22 & 23.80 \\
12 & Menganalisis & 27.77 & 33.33 \\
13 & Melakukan studi literature & 94.43 & 99.99 \\
\hline
\end{tabular}

Sedangkan aktivitas yang mengalami penurunan antara lain dapat dilihat pada tabel 2.

Tabel 2. Perbandingan Penurunan Aktivitas Belajar pada Siklus I dan II

\begin{tabular}{clcc}
\hline \multirow{2}{*}{ No. } & \multicolumn{2}{c}{ Aktivitas Siswa } & \multicolumn{2}{c}{ Persentase $(\%)$} \\
& & Siklus I & Siklus II \\
\hline 1 & Membaca referensi & 99.99 & 95.23 \\
2 & Mengamati gambar/skema & 81.09 & 66.65 \\
3 & Mengobservasi/mengamati & 72.21 & 61.9 \\
4 & Melakukan diskusi & 50 & 47.6 \\
5 & Membuat resume & 49.99 & 47.6 \\
6 & Mengerjakan tugas & 83.31 & 76.17 \\
7 & Membuat skema/gambar & 27.77 & 23.80 \\
8 & Menjelaskan & 61.1 & 57.13 \\
\hline
\end{tabular}

Tabel 3. Perbandingan Peningkatan Aktivitas Belajar pada Siklus II dan III

\begin{tabular}{clcc}
\hline No. & \multicolumn{1}{c}{ Aktivitas Siswa } & \multicolumn{2}{c}{ Persentase $(\%)$} \\
& & Siklus II & Siklus II \\
\hline 1 & Bertanya & 76.18 & 99.99 \\
2 & Menjawab pertanyaan & 33.33 & 47.36 \\
3 & Presentasi & 33.32 & 52.61 \\
4 & Menanggapi pertanyaan & 52.37 & 73.67 \\
5 & Mendengarkan presentasi/diskusi & 52.36 & 99.99 \\
6 & Menulis hasil diskusi/presentasi & 72.22 & 73.67 \\
7 & Mengerjakan tugas & 76.17 & 99.99 \\
8 & Menjelaskan & 61.1 & 68.4 \\
9 & Mengobservasi/mengamati & 61.9 & 89.46 \\
10 & Melakukan pemodelan & 33.32 & 47.35 \\
\hline
\end{tabular}


Muizudin, Penerapan strategi learning contract...

\begin{tabular}{llcl}
\hline 11 & Membuat model & 23.80 & 31.57 \\
12 & Menganalisis & 33.33 & 89.46 \\
13 & Membuat resume & 49.99 & 94.72 \\
14 & Membaca referensi & 95.23 & 99.98 \\
15 & Mengamati gambar/skema & 23.80 & 99.99 \\
16 & Melakukan diskusi & 47.6 & 57.87 \\
17 & Membuat skema/gambar & 23.80 & 26.31 \\
18 & Melakukan studi literature & 99.99 & 99.99 \\
\hline
\end{tabular}

Sedangkan aktivitas yang mengalami penurunan antara lain dapat dilihat pada tabel 4 .

Tabel 4. Perbandingan Penurunan Aktivitas Belajar yang Terjadi pada Siklus II dan III

\begin{tabular}{clcc}
\hline No. & \multicolumn{1}{c}{ Aktivitas Siswa } & \multicolumn{2}{c}{ Persentase $(\%)$} \\
& & Siklus II & Siklus II \\
\hline 1 & Menerima pendapat & 85.7 & 84.19 \\
2 & Membuat laporan & 99.99 & 99.98 \\
3 & Melakukan pengamatan/percobaan & 33.33 & 0 \\
\hline
\end{tabular}

Kreativitas bepikir siswa pada setiap siklus juga mengalami peningkatan. Ini dapat dilihat dari peningkatan rata-rata nilai siswa pada tiap siklus secara berturut-turut yakni $10.94 \%$ pada siklus I. Kenaikan sebesar $1.06 \%$ terjadi pada siklus II sehingga rata-rata nilainya menjadi $12 \%$, dan pada Siklus II Pertemuan Ke-2 kenaikan sebesar 2.68\% sehingga rata-ratanya menjadi $14.68 \%$. Peningkatan terbesar berdasarkan observasi terhadap jawaban siswa dari tesdivergen yang mereka lakukan, ternyata diketahui bahwa jenis kreativitas berpikir yang sering muncul adalah banyaknya jawaban yang orisinil dan gagasan atau ide-ide yang variatif. Cara berpikir seperti ini merupakan tanda bahwa dengan belajar sendiri siswa akan lebih banyak mendapatkan informasi dan mengembangkan informasi tersebut serta mengaplikasikannya dalam kehidupan sehari-hari. Meskipun secara rata-rata nilai kreativitas berpikir siswa selalu meningkat, namun secara jumlah persentasenya mengalami fluktuasi. Adapun peningkatan dan penurunan kreativitas berpikir siswa pada tiap siklusnya dapat dilihat pada tabel 5.

Tabel 5. Perbandingan Peningkatan Kreativitas Berpikir Siswa pada Siklus I dan II

\begin{tabular}{clcc}
\hline \multirow{2}{*}{ No. } & \multicolumn{1}{c}{ Bentuk Kreativitas } & \multicolumn{2}{c}{ Persentase (\%) } \\
Siklus I & Siklus II \\
\hline 1 & $\begin{array}{l}\text { Memberikan jawaban yang tidak lazim, yang } \\
\text { lain dari yang lain, yang jarang diberikan } \\
\text { kebanyakan orang }\end{array}$ & 100 & 100 \\
2 & $\begin{array}{l}\text { Mengembangkan, menambah, memperkaya } \\
\text { suatu gagasan }\end{array}$ & 77.77 & 80.95 \\
\hline
\end{tabular}

Tabel 6. Perbandingan Penurunan Kreativitas Berpikir Siswa pada Siklus I dan II

\begin{tabular}{clcc}
\hline No. & \multicolumn{1}{c}{ Bentuk Kreativitas } & \multicolumn{2}{c}{ Persentase (\%) } \\
& & Siklus I & Siklus II \\
\hline 1 & Menghasilkan banyak gagasan/jawaban yang & 100 & 71.42 \\
& relevan & & \\
2 & Arus pemikiran lancer & 88.88 & 85.71 \\
3 & Menghasilkan gagasan-gagasan yang seragam & 83.33 & 76.19 \\
\hline
\end{tabular}

Tabel 7. Perbandingan Peningkatan Kreativitas Berpikir Siswa pada Siklus II dan III 


\begin{tabular}{|c|c|c|c|}
\hline \multirow[t]{2}{*}{ No. } & \multirow[t]{2}{*}{ Bentuk Kreativitas } & \multicolumn{2}{|c|}{ Persentase $(\%)$} \\
\hline & & Siklus II & Siklus II \\
\hline 1 & $\begin{array}{l}\text { Menghasilkan banyak gagasan/jawaban yang } \\
\text { relevan }\end{array}$ & 71.42 & 100 \\
\hline 2 & Arus pemikiran lancer & 85.71 & 89.47 \\
\hline 3 & Menghasilkan gagasan-gagasan yang seragam & 76.19 & 100 \\
\hline 4 & $\begin{array}{l}\text { Mengembangkan, menambah, memperkaya } \\
\text { suatu gagasan }\end{array}$ & 80.95 & 94.73 \\
\hline
\end{tabular}

Tabel 8. Perbandingan Penurunan Kreativitas Berpikir Siswa pada Siklus II dan III

\begin{tabular}{clcc}
\hline \multirow{2}{*}{ No. } & \multicolumn{2}{c}{ Bentuk Kreativitas } & \multicolumn{2}{c}{ Persentase (\%) } \\
& \multicolumn{1}{c}{ Siklus II } & Siklus II \\
\hline \multirow{2}{*}{1} & $\begin{array}{l}\text { Memberikan jawaban yang tidak lazim, yang } \\
\text { lain dari yang lain, yang jarang diberikan } \\
\text { kebanyakan orang }\end{array}$ & 100 & 94.73 \\
\hline
\end{tabular}

Berdasarkan kedua grafik yang telah disajikan di atas, kita mengetahui bahwa setiap kali terjadi peningkatan aktivitas belajar terjadi juga peningkatan kreativitas berpikir. Hal ini menunjukkan bahwa adanya hubungan positif yang terjadi antara aktivitas belajar dan kreativitas berpikir. Dari kedua grafik di atas, diketahui bahwa kategori siswa berdasarkan tingkat aktivitasnya rata- rata berada pada tingkat rendah sampai sedang, begitupun dengan kreativitas berpikir siswa juga rata-ratanya berada pada tingkatan rendah sampai sedang.

Adanya kedua tingkatan ini (rendah-sedang) menunjukkan adanya peningkatan rata-rata baik aktivitas belajar maupun kreativitas berpikir pada tiapsiklusnya. Terjadinya peningkatan juga disertai terjadinya penurunan. Hal ini mungkin disebabkan karena pengaturan jam pelajaran yang tidak sama pada setiap siklusnya di mana pada siklus I siswa mendapatkan jam belajar selama 60 menit, siklus II selama 90 menit, dan Siklus II Pertemuan Ke-2 selama 60 menit. Naik turunnya jumlah jam belajar efektif ini juga berpengaruh terhadap aktivitas siswa, yakni pada jam pelajaran yang relatif sedikit maka aktivitas siswa pun menjadi terbatas.

Pada tabel 7 dan 8 (tabel perbandingan peningkatan dan penurunan aktivitas belajar pada siklus I dan II) dapat dilihat beberapa aktivitas yang mengalami peningkatan sekaligus megalami penurunan. Pada siklus II, alokasi waktu yang diperoleh siswa sebenarnya banyak yakni sebagaimana jam belajar normal (90 menit). Tapi tingkat penurunannya justru lebih banyak dari pada Siklus II Pertemuan Ke-2 (lihat tabel 10) yang alokasi waktunya hanya 60 menit saja. Hal ini kemungkinan terjadi karena faktor eksternal yang berupa teknis di mana pada siklus sebelumnya (siklus I) untuk kegiatan pembelajaran tertentu seperti kajian literatur dari berbagai informasi yang semula dilaksanakan di ruang perpustakaan pada siklus II ternyata ruang perpustakaan digunakan oleh kelas lain sehingga siswa harus berpindah ke ruang internet. Setiap kali perubahan tempat membutuhkan waktu, sehingga alokasi waktu yang sedianya sudah dirancang sedemikian rupa oleh siswa untuk melakukan aktivitasnya sesuai rancangan kegiatan mengalami pengurangan waktu bahkan siswa harus melengkapi dirumah sebagai tugas kelompok.Namun meskipun demikian, kegiatan ini ternyata tetap memberikan pengaruh positif terhadap kreativitas berpikir siswa di mana semakin banyak kesempatan siswa untuk melakukan aktivitas, memperoleh pengalaman dan pengetahuan semakin berpengaruh terhadap tingkat kreativitas berpikir siswa. Ini terlihat dari kenaikan rata-rata nilai tingkat kreativitas berpikir siswa pada setiap siklusnya. Yakni dari tingkat rendah pada siklus I menjadi tingkat sedang pada siklus II dan III. Namun meskipun rata-rata nilainya meningkat, pada siklus II kreativitas berpikir siswa juga mengalami penurunan. Hal ini mungkin disebabkan mulai menurunnya motivasi siswa sehingga siswa sudah mulai enggan untuk berpikir. 
Dalam strategi Learning Contract guru berperan sebagai mediator dan fasilitator yang memberikan acuan atau alat, sehingga yang aktif dan mendominasi aktivitas adalah siswa. Kebebasan yang diberikan siswa dalam strategi ini memungkinkan siswa untuk menggali sebanyak-banyaknya ilmu pengetahuan yang berkaitan dengan materi, baik secara toeritis mapun secaraempiris. Menurut Piaget, bahwa seseorang anak itu berpikir sepanjang ia berbuat. Tanpa perbuatan berarti anak itu tidak berpikir. Oleh karena itu, agar anak berpikir sendiri maka harus diberi kesempatan untuk berbuat sendiri. Dengan strategi ini siswa banyak mendapatkan kesempatan untuk mengembangkan kreativitas berpikir dan melakukan aktivitas sebanyak- banyaknya. Hal ini sesuai dengan hakikat siswa sebagai anak didik yakni manusia yang memliki potensi yang bisa berkembang secara optimal apabila kondisinya mendukung.

Hampir semua jenis kegiatan yang dilakukan siswa adalah moving class, maksudnya siswa tidak hanya melakukan kegiatan belajar di kelas melainkan di tempat lain yang dianggap sesuai untuk melakukan kegiatan. Beberapa tempat yang digunakan siswa dalam penelitian ini antara lain laboratorium, perpustakaan, ruang internet, dan kelas. Dengan kondisi seperti ini, peneliti sedikit mengalami kesulitan untuk dapat mengkondisikan siswa. Apalagi mengingat kegiatan belajar yang dilakukan adalah kegiatankelompok, maka peneliti pun harus menyediakan banyak observer. Tapi semua itu dapat teratasi. Dengan ketersediaan observer yang cukup, masing- masing kelompok didampingi oleh seorang observer, sedangkan peneliti dan kolaborator berfungsi selain sebagai pendamping dan fasilitator juga ikut mengamati jalannyakegiatan.

Pada siklus II, terjadi beberapa penurunan aktivitas dan kreativitas berpikir siswa. Hal ini terjadi karena motivasi siswa untuk belajar sudah mulai mengalami penurunan. Untuk mengatasinya, guru memberikan motivasi dalam bentuk ucapan atau kata-kata yang dianggap mampu memberikan semangat bagi siswa. Dan motivasi ini ternyata memberikan hasil. Keberhasilan itu terlihat dari peningkatan aktivitas siswa pada siklus ke III. Meskipun pada siklus ke-3 juga terjadi juga penurunan tehadap beberapa aktivitas siswa, namun bukan diakibatkan karena motivasi yang menurun tetapi lebih karena aktivitas tersebut memang sudah tidak lagi dilakukan mengingat kegiatan yang dilakukan pada Siklus II Pertemuan Ke-2 adalah penyampaian laporan hasil kegiatan siswa dalam bentukpresentasi.

Beberapa faktor lain yang mungkin menjadi penyebab penurunan aktivitas belajar siswa adalah kegiatan belajar yang moving class sehingga memakan banyak waktu menyebabkan siswa tidak bisa menyelesaikan secara maksimal seluruh rancangan kegiatan, faktor eksternal baik teknis maupun nonteknis seperti tidak dapat digunakannya ruangan internet sebagai salah satu sumber belajar pada setiap kegiatan belajar, kurangnya jam pelajaran karena terpotong dengan kegiatan sekolah, serta faktor eksternal lainnya yang mungkin berpengaruh terhadap terjadinya penurunantersebut.

\section{Kesimpulan}

Berdasarkan hasil penelitian yang didapatkan, penulis menarik kesimpulan bahwa strategi Learning Contract dapat dilaksanakan sebagai strategi pembelajaran pada materi pokok listrik Statis di kelas IX A SMP Negeri Sistem gerak. Banyaknya siklus yang dibutuhkan untuk dapat meningkatkan kreativitas berpikir dan aktivitas belajar IPA siswa kelas IX A SMP Negeri I Sumber Kabupaten Cirebon adalah sebanyak 3 siklus.

\section{Daftar Pustaka}

Apriyani, A. (2016). Penerapan Metode Learning Contract Untuk Meningkatkan Kreativitas Belajar Siswa Pada Mata Pelajaran Qur'an Hadits Di Madrasah Ibtidaiyah Qur'aniah $1 v$ Palembang (Skripsi) (Doctoral dissertation, UIN Raden Fatah Palembang).

A'yun, Q., Dewi, N. R., \& Sudarmin, S. (2015). Efektivitas model think pair square (tps) berbasis guided inquiry pada tema sistem transportasi untuk meningkatkan hasil belajar kognitif dan sikap ilmiah siswa. Unnes Science Education Journal, 4(3). 
Azizah, A., \& Winarti, P. (2016). Pengaruh Penggunaan Metode Guided Discovery Terhadap Hasil Belajar Ipa Siswa Kelas Iv Sekolah Dasar. Profesi Pendidikan Dasar, 3(1), 1-11.

Eliyana, E. (2020). Analisis Keterampilan Proses Sains Siswa Belajar IPA Materi Tumbuhan Hijau Pada Siswa Kelas V SDN 3 Panjerejo di Masa Pandemi Covid-19. EDUPROXIMA: Jurnal Ilmiah Pendidikan IP A, 2(2), 87-100.

Fitria, N. (2019). Upaya Meningkatkan Hasil Belajar Ekonomi Menggunakan Metode Learning Contract Pada Siswa Kelas X Smk Yadika Natar Lampung Selatan. Lentera: Jumal Ilmiah Kependidikan, 11(1), 81-86.

Fitriana, S. (2017). Penerapan Model Pembelajaran Eksploratif dengan Metode Inquiry Labs untuk Meningkatkan Pemahaman Konsep Siswa pada Konsep Elastisitas. Keguruan, 5(1).

Halidjah, S., \& Margiati, K. Y. (2014). Peningkatan Hasil Belajar Siswa dalam Pembelajaran IPA Menggunakan Media Realita di Sekolah Dasar.Jurnal Pendidikan dan Pembelajaran Khatulistiwa, 3(7).

Harefa, A. R. (2016). Penggunaan Pendekatan Keterampilan Proses dalam Pembelajaran IPA. Warta Dharmawangsa, (50).

Irjan, I. (2008). Optimalisasi Proses Dan Hasil Pembelajaran Ilmu Pengetahuan Alam (IPA) Pada Sekolah Dasar (SD)/Madrasah Ibtidaiyah (Mi). Madrasab: Jurnal Pendidikan dan Pembelajaran Dasar, 1(1).

Jasmin, J., Sriyono, S., \& Ngazizah, N. (2015). Model Pembelajaran Kooperatif TGT Untuk Meningkatkan Keaktifan Siswa Dalam Belajar IPA. Radiasi : Jumal Berkala Pendidikan Fisika, 6(1), 96-100.

Juhji, J. (2017). Pembelajaran Sains Pada Anak Raudhatul Athfal. As-Sibyan: Jurnal Pendidikan Anak Usia Dini, 1(01), 49-59.

Kumara, A. (2004). Model pembelajaran "Active Learning" mata pelajaran sains tingkat SD Kota Yogyakarta sebagai upaya peningkatan "Life Skills". Jurnal psikologi, 31(2), 63-91.

Nurdin, S. (2017). Guru Profesional dan Penelitian Tindakan Kelas. Jurnal El-Rusyd, 1(1), 59-80.

Saputro, B. C. (2017). Meningkatkan Hasil Belajar Sifat-sifat Cahaya dengan Metode Inquiri Pada Kelas V Semester II SDN Sumogawe 04. e-Jurnal Mitra Pendidikan, 1(9), 925-937.

See, S., Sadipun, B., Wali, M., We'u, G., Abdullah, A. N., Pali, A., \& Arafat, S. (2021). Pelatihan Penyusunan Proposal PTK Kepada Para Guru Sekolah Dasar Di Gugus 3 Kabupaten Ende. Prima Abdika: Jurnal Pengabdian Masyarakat, 1(1), 7-13.

Suhara, A. M., \& San Fauziya, D. (2017). Penerapan strategi active learning tipe kontrak belajar dalam kegiatan menulis artikel. Literasi: Jurnal Ilmiah Pendidikan Bahasa, Sastra Indonesia Dan Daerah, 7(1), 71-85.

Suhendi, s. (2017). Pembelajaran Sains Dalam Desain Pendekatan Tematik Integratif. Tarbawijab: Jurnal Ilmiah Pendidikan, 11(02), 221-234.

Sulthon, S. (2016). Pembelajaran IPA Yang Efektif Dan Menyenangkan Bagi Siswa MI. Elementary, 4(1).

Tias, I. W. U. (2017). Penerapan Model Penemuan Terbimbing untuk Meningkatkan Hasil Belajar IPA Siswa Sekolah Dasar. DWIJA CENDEKIA: Jurnal Riset Pedagogik, 1(1).

Wati, S. L., Laganing, N. L. N., \& Gagaramusu, Y. (2015). Penerapan Pendekatan Keterampilan Proses Dalam Meningkatkan Pemahaman Siswa Terhadap Konsep Pernapasan Pada Tumbuhan di Kelas IV SDN 2 Laantula Jaya Kecamatan Wita Ponda Kabupaten Morowali. Jurnal Kreatif Online, 3(2). 